\author{
L. Jaworska ${ }^{1}$, W. Zebala ${ }^{2}$, P. Rutkowski ${ }^{3}$, S. Cygan ${ }^{1, *}$, \\ P. Klimczyk ${ }^{1}$, P. Putyra ${ }^{1}$ \\ ${ }^{1}$ Centre for Materials Research and Sintering Technology, \\ Institute for Advanced Manufacturing Technology, Krakow, Poland \\ ${ }^{2}$ Faculty of Mechanical Engineering, Kracow University \\ of Technology, Krakow, Poland \\ ${ }^{3}$ Department of Ceramics and Refractories, \\ University of Science and Technology, Krakow, Poland \\ *slawomir.cygan@ios.krakow.pl
}

\title{
Temperatures during the dry cutting of titanium alloy using diamond composites with ceramic bonding phases
}

In this paper the thermal properties of diamond composites with ceramic bonding phases, such as the Ti-Si-C system with nanometric Ti(CN) and $\mathrm{TiB}_{2}$ are presented. The thermal conductivities of the materials were analyzed by the laser pulse method. In addition, computational simulations of the temperature dependence on the distance from the cutting edge were performed according to the finite element method for the investigated composites, commercial PCD, and hypothetical diamond monocrystal. Two cutting speeds were considered during the numeric computations: 100 and $200 \mathrm{~m} / \mathrm{min}$. To verify the simulations, the TNGA 160408 cutting insert, which was prepared from the investigated diamond composites and commercial material, was employed. Dry turning tests of titanium alloy were conducted. The temperatures during the machining processes were observed using a thermovision camera, and the surface roughness was measured after the tests. The computational simulations confirmed the strong dependence between the thermal properties of the cutting material and the temperatures within the cutting zone. The temperature measurements during the dry cutting tests reveal significantly higher temperatures than the temperature measurements achieved during the simulations.

tools, turning.

Keywords: diamond-ceramic composite, thermal properties, cutting

\section{INTRODUCTION}

Synthetic diamond can be fabricated by chemical vapour deposition (CVD) or high temperature and pressure (HP-HT) synthesis. During HP-HT synthesis (at approximately 5-6 GPa, 1670-1770 K) submicrometric and micrometric diamond powders are primarily obtained from carbon precursors. Large diamond crystals or polycrystals are employed for cutting tool applications. The chemical composition and properties of the synthetic diamond obtained using the high pressure-high temperature method are dependent on the type of the catalyst [1]. In 1958, Hall disclosed the possibility of fabricating polycrystalline diamond by high pressure and high temperature sintering of diamond powder with additives of refractory metals, transition metals, and other materials [2].

Polycrystalline diamond (PCD), which is sintered by the HP-HT method, is the most popular form of diamond tool materials. For cutting tool edge applications,

(C) L. JAWORSKA, W. ZEBALA, P. RUTKOWSKI, S. CYGAN, P. KLIMCZYK, P. PUTYRA, 2017 
diamond compacts have been employed since the early 1970s. Katzman and Libby have investigated liquid phase sintering of the diamond-cobalt system [3]. Hibbs and Wentorf have developed a method of cobalt infiltration into diamond layers under high pressure conditions [4]. Diamond powders were sintered and simultaneously bonded to a $\mathrm{WC}-\mathrm{Co}$ substrate by infiltration of Co from the substrate. The carbide substrate is very useful for tool producers as it enables brazing to the tool body. Sufficiently high wettability of diamond materials by molten metal fillers is the principal requirement for successful brazing. The most popular commercial PCDs consist of two-layer materials with a cobalt phase. Cobalt provides adequate wetting of diamond crystallites. This property enables the production of compacts, which are characterized by a low amount (below $10 \mathrm{wt} \%$ ) of bonding phase and produce high hardness. The benefit of the utilization of binder materials for the sintering of diamond compacts is three-fold: a reduction in the sintering temperatures and pressures, cleaning of the diamond surface of graphite, and the electrical discharge cuttability for tool making [4]. These materials are characterized by a special microstructure that is composed of fine initial diamond grains surrounded by the metal and new, very small and recrystallized diamond crystals.

Polycrystalline-diamond-based tool materials with metal solvent/catalyst binders, such as cobalt, are extensively used for wire drawing dies, rock drilling bits [5], and stone cutting segments in cutting applications [6]. Studies have been performed to investigate the use of PCD tools for very precise machining applications, such as the ultraprecision cutting of $\mathrm{WC}-\mathrm{Co}$ [7] and the micro-core drilling of circuit boards and fiber-reinforced composites [8]. Note that Cocontaining PCDs are chemically stable at temperatures below $970 \mathrm{~K}$; however, working temperatures may be higher. Due to the extensive use of these materials and temperature limitations (from the current use of metallic binders), the development of new bonding phases in diamond composites is significantly needed. One of the possibilities for increasing the thermal resistance of PCD materials is the reduction of the cobalt bonding phase content by sintering without metal solvent/catalyst or without any additional binding material. The solution involves the preparation of the materials with a nonmetallic bonding phase and without the negative effects of the bonding phase (such as diamond-graphite solvent catalyst) on diamond graphitization. Although commercial PCDs are very hard and extremely wear-resistant, their poor thermal stability causes decomposition at high temperatures. Instead of dissolving carbon in the cobaltbonding phase, other materials can be employed, for example $\mathrm{Ti}_{3} \mathrm{SiC}_{2}$ and $\mathrm{TiB}_{2}$. The addition of the thermally resistant phase to diamond (PCD) can facilitate the use of the diamond cutting edge at higher temperatures to obtain a higher resistance not only to graphitization but also to oxidation at elevated temperatures. New types of composites, which consist of micron-sized diamonds with borides, were investigated with regard to their resistance to high temperatures below $1070 \mathrm{~K}$, such as the temperature in the cutting zone (the area of the tool material, which is in contact with the workpiece) [9]. Carbides are not thermally resistant bonding phases for diamond materials due to their low oxidation temperatures. The thermal resistance of diamond composites is more dependent on the oxidation process compare with the graphitization process. $\mathrm{CO}$ gas evolution during diamond composite oxidation destroys the integrity of the composite microstructure [9].

The temperature in the cutting zone is one of the most important parameters that affecting cutting performance. Temperature influences the feasibility of high cutting speeds, feeds, depth of cut and the tool life. It influences the productivity 
and economic efficiency of production indirectly but significantly. Heat balance is a form of energy balance, and total heat in the cutting zone consists of heat in the workpiece, heat in the tool, heat in the chip and exhausted heat. The temperature of a chip has the highest value as it also consists of the heat from deformation. A smaller amount of heat is received by the tool (consists of the part of the heat from deformation and the part of the heat from the friction between the tool surface and the transitional area of the workpiece) [10]. Crucial properties of cutting tool material include hardness and strength, which must be maintained at elevated temperatures (hot hardness); toughness is needed to prevent tools from chipping or fracturing, especially during interrupted cutting operations; and wear resistance is critical to obtain an acceptable tool life before the tool needs to be replaced [11].

Diamond content and diamond grain size distribution are carefully controlled to provide the correct balance of wear resistance and toughness [1]. For cutting materials with a bonding phase other than cobalt, thermal properties are subjected to change. Ceramic materials exhibit a differentiation of properties, such as thermal and electrical conductivities, hardness, abrasive wear resistance and corrosion resistance, resistance to temperature change and chemical inertness towards the workpiece material. These characteristics influence the type of machining and are important for metal cutting process modeling. Thermal properties are important for diamond tool materials due to oxidation and graphitization processes. Tool temperature has a significant influence on the tool wear. New and thermally resistant bonding phases in PCD-type materials may improve their thermal resistance and tribological properties; as a result, they may have influence on the temperature generated in the cutting zone. Different wear mechanisms, such as abrasion, adhesion, micro-cracking and fatigue, have been employed to explain the flank wear of PCD tools; however, the wear of PCD tools is not completely understood [12]. A high resistance to oxidation and the phase transition bonding phase for diamond composites improves the temperature resistance of the tools, whereas changing the coefficient of friction can generate more heat in the cutting zone. In addition to the $\mathrm{TiB}_{2}$ bonding phase for diamond compacts, the diamond compact with the $\mathrm{Ti}-\mathrm{Si}-\mathrm{C}-\mathrm{TiCN}_{(n)}$ bonding phase and the commercial PCD with cobalt bonding phase were also investigated.

\section{EXPERIMENTAL}

\section{Materials}

First, the mixtures containing $80 \mathrm{wt} \%$ diamond (3-6 $\mu \mathrm{m}$ MDA, Element Six), $15 \mathrm{wt} \%$ of $\mathrm{Ti}-\mathrm{Si}-\mathrm{C}\left(47.1 \mathrm{vol} \% \mathrm{Ti}_{3} \mathrm{SiC}_{2}, \mathrm{TiSi}_{2}, \mathrm{TiC}\right.$ and $\mathrm{SiC}$ manufactured using the SHS technique, AGH, Poland) and $5 \mathrm{wt} \%$ nanometric $\mathrm{Ti}(\mathrm{CN})$ (Neomat $\mathrm{Co}$, Lithuania) powders were prepared. The second material was prepared using the same diamond powder with $10 \mathrm{wt} \%$ of titanium diboride (American Elements, $<100 \mathrm{~nm}$ ) and $2 \%$ Co (Sigma-Aldrich, $2 \mu \mathrm{m}$ ). The mixtures were pressed into cylindrical shapes of $15-\mathrm{mm}$ diameter at $90 \mathrm{MPa}$. Next, they were sintered using a Bridgman-type high-pressure apparatus at $8.0 \pm 0.2 \mathrm{GPa}$ and a temperature of $2070 \pm 50 \mathrm{~K}$. The samples were heated in an internal graphite heater with an inside diameter of $15 \mathrm{~mm}$. The third material was the commercial PCD that contains $88 \mathrm{wt} \%$ of diamond (with an average grain size of $4 \mu \mathrm{m}$ ), $10 \mathrm{wt} \%$ of Co and $2 \mathrm{wt} \%$ of WC. Some of these materials properties are presented in the table.

The density was measured using the hydrostatic method. Hardness measurements were performed with a Vickers apparatus at $9.8 \mathrm{~N}$ loads. Young's modulus was measured using the ultrasonic method. 
Selected properties of diamond composite with ceramic bonding phase $[13,14]$

\begin{tabular}{c|c|c|c}
\hline $\begin{array}{c}\text { Composition, } \\
\text { wt } \%\end{array}$ & $\begin{array}{c}\text { Density } \\
\mathrm{g} / \mathrm{cm}^{3}\end{array}$ & $\begin{array}{c}\text { Hardness } \\
\mathrm{GPa}\end{array}$ & $\begin{array}{c}\text { Young modulus, } \\
\mathrm{GPa}\end{array}$ \\
\hline $\begin{array}{c}80 \% \text { diamond }+15 \%(\mathrm{Ti}-\mathrm{Si}-\mathrm{C}) \\
+5 \% \text { nano } \mathrm{TiCN}\end{array}$ & $3.5 \pm 0.01$ & $49.6 \pm 3.6$ & $706 \pm 18$ \\
$\begin{array}{c}9 \% \text { diamond }+5 \% \mathrm{TiB}_{2}+2 \% \mathrm{Co} \\
\text { ( } 4.04 \pm 0,01\end{array}$ & $66.6 \pm 2.9$ & $834 \pm 23$ \\
$\begin{array}{c}8 \% \text { diamond }+10 \% \mathrm{Co}+ \\
2 \% \text { WC (commercial) }\end{array}$ & $4.13 \pm 0.01$ & $75.5 \pm 7.3$ & $972 \pm 34$ \\
\hline
\end{tabular}

*Average measurement for three samples.

**Average of five hardness measurements, the statistical significance $\alpha=0.05$.

Diamond with $\mathrm{TiB}_{2}$ and Co composite is the most resistant to the hardness changes at elevated temperatures from the materials investigated in $[9,14]$. This material maintains a high hardness value at temperatures below $1070 \mathrm{~K}$. For the diamond with the $\mathrm{Ti}-\mathrm{Si}-\mathrm{C}-\mathrm{N}$ bonding phase, the hardness decreases above $940 \mathrm{~K}$, this is similar to the commercial PCD material with the cobalt bonding phase [9, 14]. For diamond with $\mathrm{TiB}_{2}+\mathrm{Co}$ and for commercial material with a Co bonding phase, a participation of tungsten ( $\mathrm{W}$ is the additive from the milling process) is evident. WC influences the decrease of the thermal resistance of the materials. The diamond $+\mathrm{TiB}_{2}+\mathrm{Co}$ composite bonding phase after sintering also contains $\mathrm{W}_{2} \mathrm{CoB}_{2}$. This compound is thermally stable and very hard; it also significantly decreases the coefficient of friction [14].

\section{Thermal properties}

Heat measurements were performed on a Netzsch LFA 427 apparatus. The thermal diffusivity and conductivity were determined by the laser pulse method (LFA) using "Cape-Lehman + pulse correction" calculations model offered by the Netzsch software $[15,16]$. The test program was conducted in argon flow as referenced in the program measurements presented in Fig. 1. The laser voltage was $480 \mathrm{~V}$; the pulse width was $0.8 \mathrm{~ms}$; and the flow rate of argon was $150 \mathrm{ml} / \mathrm{min}$. The diameter of the samples was $10 \mathrm{~mm}$, and the thickness was approximately $4 \mathrm{~mm}$. If the value for thermal conductivity is unknown, it can be calculated from the thermal diffusivity, the density and the specific heat capacity of the material.

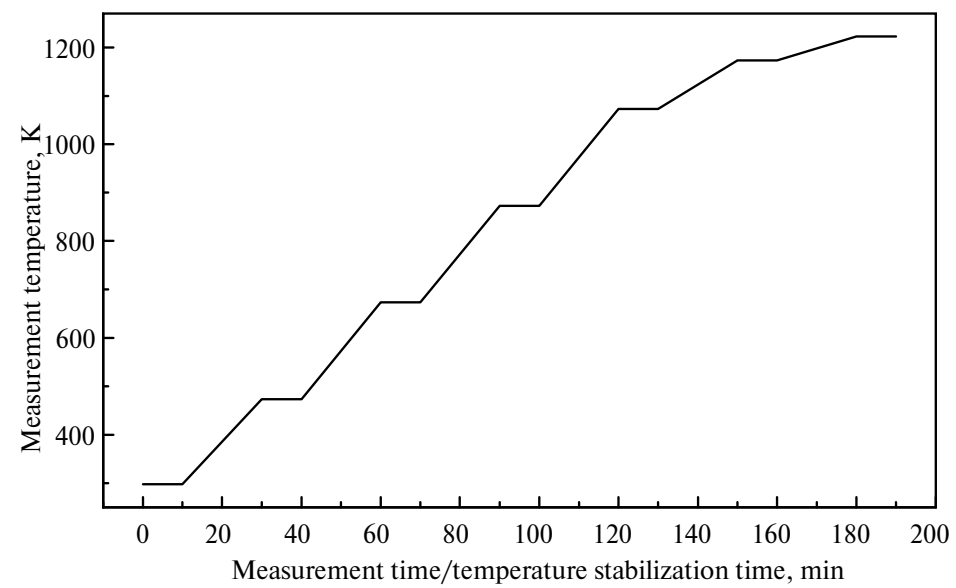

Fig. 1. Program of the temperature change for the thermal diffusivity measurements, performed with LFA 427 (laser flash analysis). 
Heat capacity can be measured with the LFA method by comparing the temperature rise of the sample to the temperature rise of the reference sample of known capacity tested under the same conditions [15]. This temperature rise is recorded during the diffusivity measurement, so specific heat can be calculated from the same data with a suitable calibration. To determine the specific heat with LFA method, the Pyroceram 9606 and Inconel patterns with known coefficients of thermal expansion and specific heat were used as the reference. The specific heat of the diamond composite was calculated from equation implemented in the Netzsch LFA 427 software documentation:

$$
c_{p}^{\text {samp }}=\frac{T_{\infty}^{\text {ref }}}{T_{\infty}^{\text {samp }}} \cdot \frac{Q^{\text {samp }}}{Q^{\text {ref }}} \cdot \frac{V^{\text {samp }}}{V^{\text {ref }}} \cdot \frac{\rho^{\text {ref }} D^{\text {ref }}}{\rho^{\text {samp }} D^{\text {samp }}} \cdot \frac{d_{\text {orifice }}^{2, \text { samp }}}{d_{\text {orifice }}^{2, \text { samp }}} \cdot c_{p}^{\text {ref }},
$$

where $c_{p}$-specific heat of samples/reference patterns, $\mathrm{J} / \mathrm{gK} ; T$ - samples/reference pattern temperature, $\mathrm{K} ; Q$ - energy absorbed by the sample/reference pattern, $\mathrm{J} ; V-$ amplitude of the signal gain of the sample/reference pattern; $\rho$ - apparent density, $\mathrm{g} / \mathrm{cm}^{3} ; D$ - thickness of samples, $\mathrm{mm} ; d$ - diameter of samples/ref. pattern measurement area, $\mathrm{mm}$.

\section{Numerical computation of temperature at the cutting edge}

The numerical computations were performed according to the finite element method [17]. The computational simulations were conducted for the investigated diamond composites and hypothetical diamond monocrystal. The simulations were performed to analyze the temperature dependence on the distance from the cutting edge for 100 and $200 \mathrm{~m} / \mathrm{min}$ cutting speeds.

\section{Temperature measurements during turning of titanium alloy}

The TNGA 160408 cutting insert was prepared from the investigated diamond composites. The Thermovision camera type Flir SC 620 with Therma CAM Researcher software was employed for the temperature measurements during the dry cutting tests (turning) for the $\mathrm{Ti}_{6} \mathrm{Al}_{4} \mathrm{~V}$ alloy workpiece. The following cutting parameters were applied: cutting speed $v_{c}=30-200 \mathrm{~m} / \mathrm{min}$, feed $f=0.105 \mathrm{~mm}$ and depth of cut $a_{p}=0.5 \mathrm{~mm}$. The test also measured the surface roughness.

\section{RESULTS AND DISCUSSION}

Due to the high melting temperatures of the ceramic bonding phases, higher temperatures are required for the sintering process (maximum temperature of $2670^{\circ} \mathrm{K}$ and pressure of $7.8 \mathrm{GPa}$ were used) for the diamond-ceramic composite compared with the cobalt bonding phase.

Natural diamond has a higher thermal conductivity than any other known material [18]. For synthetic diamond, the thermal conductivity is in the vicinity of $1000 \mathrm{~W} / \mathrm{mK}$. The thermal conductivity of the composites obtained from the natural particulate diamond with a size in the range of 10 to $14 \mu \mathrm{m}$ was approximately $500 \mathrm{~W} / \mathrm{mK}$ [10]. For the polycrystalline synthetic diamond that contains a maximum of $1.5 \%$ impurities and inclusions, with a size range of 10 to $14 \mu \mathrm{m}$, the thermal conductivity is approximately $190 \mathrm{~W} / \mathrm{mK}$ [19]. The thermal conductivity at room temperature for commercial diamond compacts with a maximum cobalt bonding phase of $10 \mathrm{vol} \%$ is in the range of 150 to $600 \mathrm{~W} / \mathrm{mK}$ [20]. The thermal properties of the interface that separate the diamond particles and the properties of the bonding phase are very significant for the thermal conductivity of the diamondceramic composite [21]. The thermal conductivities of the refractory metals and the carbides usually range from $7-170 \mathrm{~W} / \mathrm{mK}$. The thermal conductivity of $\mathrm{SiC}$ is in 
the range $40-145 \mathrm{~W} / \mathrm{mK}$, whereas the thermal conductivity of TiC is $21 \mathrm{~W} / \mathrm{mK}$ [22]. The presence of these ceramics decreases the thermal conductivity of the diamond composite. A low value of thermal conductivity for the cutting edge affects the presence of polycrystalline grain boundaries and their incoherency. High thermal conductivity ensures rapid heat transfer from the cutting zone and is less affected by the changes in the surface of the diamond tools. The thermal conductivities for the investigated materials are presented in Fig. 2. Diamond$\mathrm{TiB}_{2}-\mathrm{Co}$ has a much higher thermal conductivity than diamond-Ti-Si-C-TiCN $(n)$, which have a thermal conductivity at room temperature of 205 and $74 \mathrm{~W} / \mathrm{mK}$, respectively. Diamond with $\mathrm{TiB}_{2}$ addition is characterized by a significant decrease of the thermal conductivity with an increase in temperature, despite a thermal conductivity of $156.5 \mathrm{~W} / \mathrm{mK}$ at $873 \mathrm{~K}$. At this temperature, the composite with the addition of $\mathrm{Ti}-\mathrm{Si}-\mathrm{C}$ and $\mathrm{TiCN}$ had a thermal conductivity of approximately $64 \mathrm{~W} / \mathrm{mK}$.

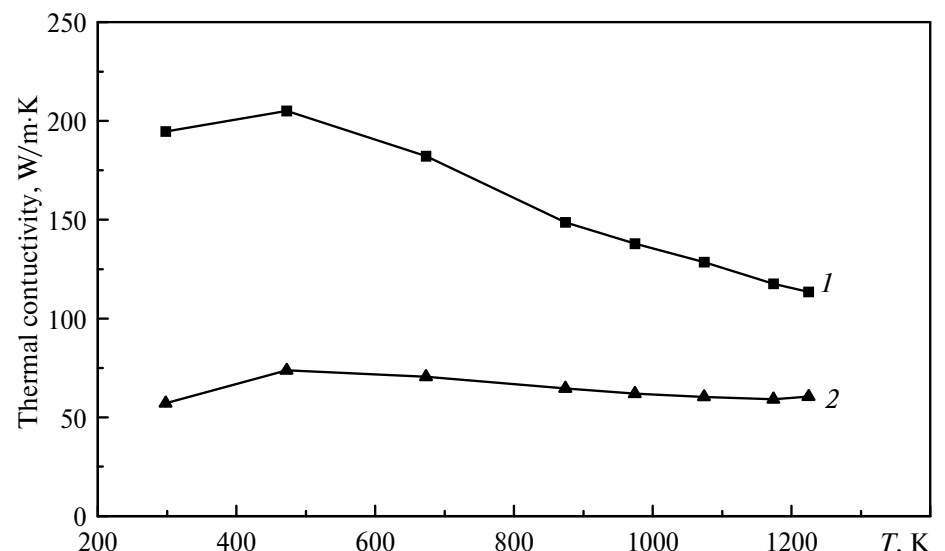

Fig. 2. Thermal conductivities of the diamond-Ti-Si-C-TiCN and the diamond- $\mathrm{TiB}_{2}$ composites: $80 \%$ diamond $+15 \%$ Ti-Si-C+ $5 \%$ nano $\mathrm{TiCN}(1), 93 \%$ diamond $+5 \% \mathrm{TiB}_{2}+2 \% \mathrm{Co}$ (2).

The computational simulations were performed for materials with 64 and $156 \mathrm{~W} / \mathrm{mK}$ of thermal conductivity (which corresponds to the thermal conductivity of the investigated materials at $873 \mathrm{~K}$ ) and the hypothetical diamond monocrystal $(1000 \mathrm{~W} / \mathrm{mK})$. Figure 3 shows the temperature dependence on the distance from the cutting edge (in the direction of the rake and the relief face) for the turning process using the following parameters: cutting speed $v_{c}=200 \mathrm{~m} / \mathrm{min}$, feed $f=0.1 \mathrm{~mm} / \mathrm{rev}$ and depth of cut $a_{p}=0.5 \mathrm{~mm}$. This computational simulation reveals that temperatures at the cutting zone attain temperatures of 973,870 and $510 \mathrm{~K}$ for materials with thermal conductivities of 64,156 and $1000 \mathrm{~W} / \mathrm{mK}$, respectively. These calculations confirm the strong dependence between the thermal properties and the temperatures that are generated in the cutting zone.

Figures 4 and 5 were also prepared using computational simulations for diamond composites with thermal conductivities of 156 and $64 \mathrm{~W} / \mathrm{mK}$. The temperature dependence on the distance from the cutting edge for 100 and $200 \mathrm{~m} / \mathrm{min}$ cutting speeds for the materials is shown. The lower value of the cutting speed influences the lower value of the cutting edge temperature. However, the machining processes at low cutting speeds are less effective.

Many parameters influence the machining process and temperature at the cutting zone. For example, the temperature in the cutting zone is dependent on the 
tool geometry, the machining parameters, the cutting forces, the friction between the tool and the workpiece material and the thermal and mechanical properties of both the workpiece and the cutting material.

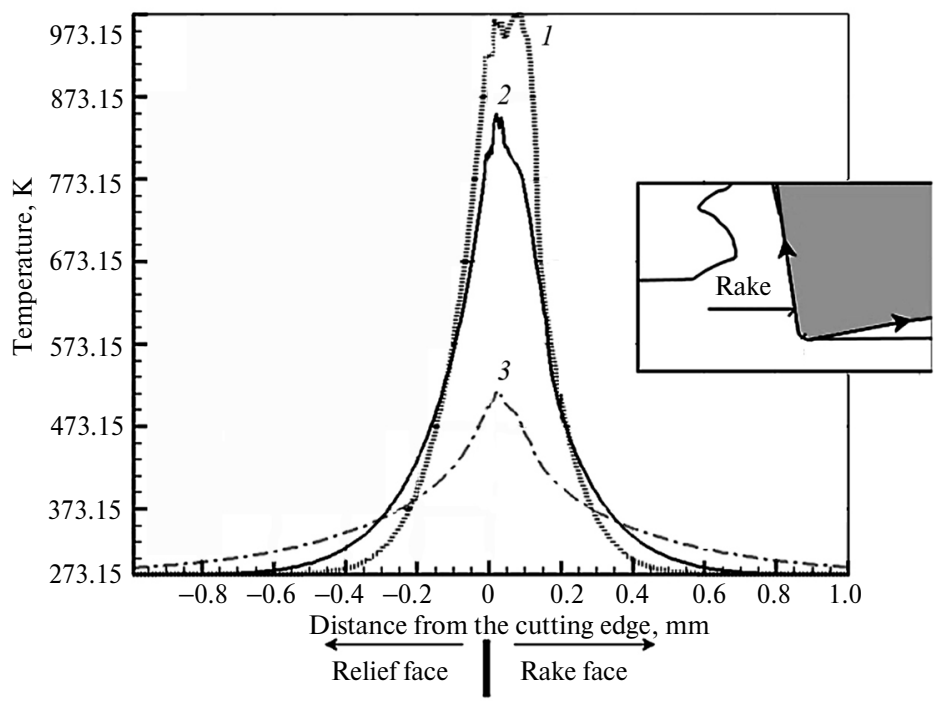

Fig. 3. Numerical computation of the temperature dependence on the distance from the cutting edge for diamond-Ti-Si-C-TiCN, diamond- $\mathrm{TiB}_{2}$ composites and hypothetical diamond monocrystal with thermal conductivities of $64(1), 156(2)$ and $1000(1) \mathrm{W} / \mathrm{mK} ; v_{c}=200 \mathrm{~m} / \mathrm{min}$, $f=0.1 \mathrm{~mm}, a_{p}=0.5 \mathrm{~mm}$.

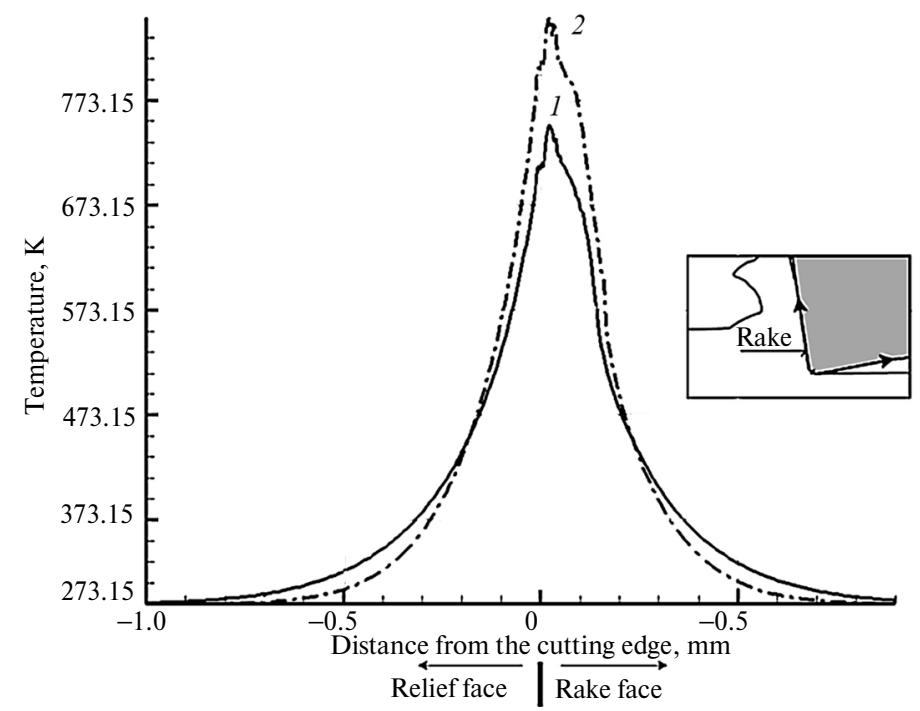

Fig. 4. Numerical computation of the temperature dependence on the distance from the cutting edge for diamond composite with a thermal conductivity of $156 \mathrm{~W} / \mathrm{mK}$ at cutting speeds of $100(1)$ and $200(2) \mathrm{m} / \mathrm{min} ; f=0.1 \mathrm{~mm}, a_{p}=0.5 \mathrm{~mm}$.

In Fig. 6, the maximal measured temperatures for the dependence on cutting speed are presented for investigated materials. The lowest temperature values were obtained for the composite that consists of $93 \%$ diamond with $5 \% \mathrm{TiB}_{2}$ and $2 \%$ Co. For the material with a $\mathrm{Ti}-\mathrm{Si}-\mathrm{C}-\mathrm{TiCN}$ system bonding phase, the highest temperatures were recorded for cutting speeds that ranged from 40 up to $80 \mathrm{~m} / \mathrm{min}$; tool failure occurred at speeds above this speed range. 


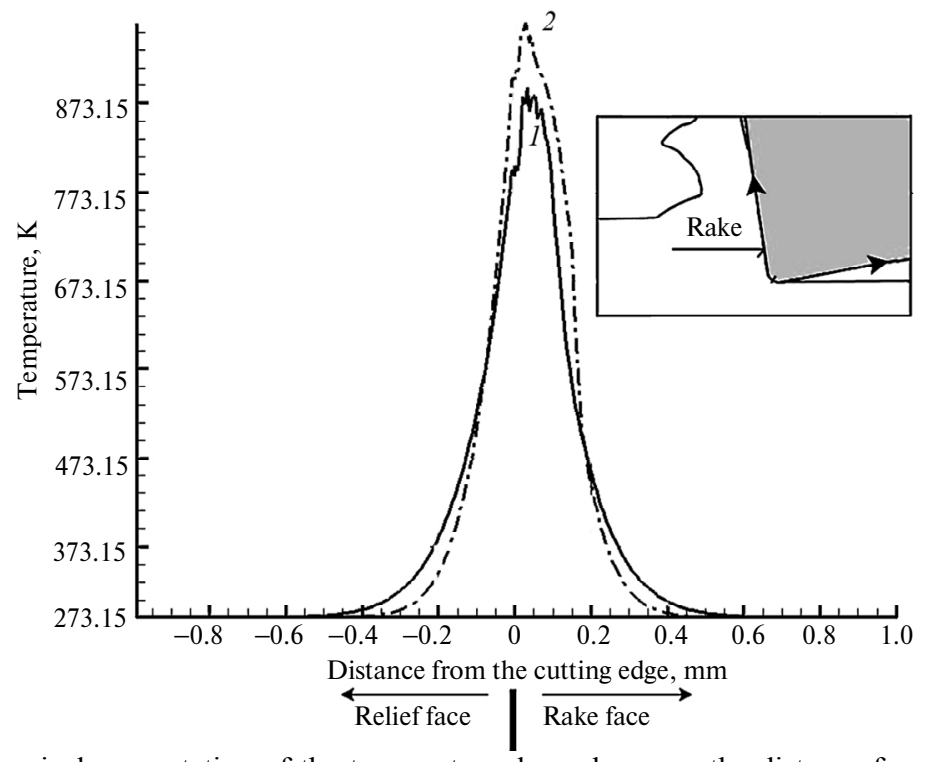

Fig. 5. Numerical computation of the temperature dependence on the distance from the cutting edge for diamond composite with a thermal conductivity of $64 \mathrm{~W} /(\mathrm{m} \cdot \mathrm{K})$ at cutting speeds of $100(1)$ and $200(2) \mathrm{m} / \mathrm{min} ; f=0.1 \mathrm{~mm}, a_{p}=0.5 \mathrm{~mm}$.

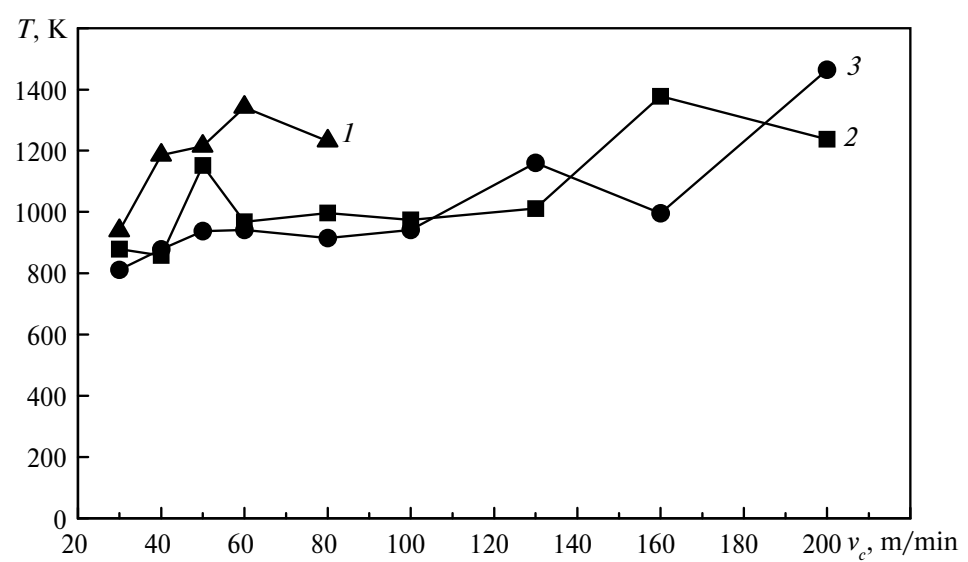

Fig. 6. Maximum temperature in the cutting zone for the dependence on cutting speed for diamond-Ti-Si-C-TiCN, diamond- $\mathrm{TiB}_{2}-\mathrm{Co}$ and commercial composite: $80 \%$ diamond + $15 \%(\mathrm{Ti}-\mathrm{Si}-\mathrm{C})+5 \%$ nano $\mathrm{TiCN}(1), 93 \%$ diamond $+5 \% \mathrm{TiB}_{2}+2 \% \mathrm{Co}(2), 88 \%$ diamond + $10 \% \mathrm{Co}+2 \% \mathrm{WC}$ (commercial) (3).

Thermovision measurements indicated a temperature of approximately $1000 \mathrm{~K}$ at the cutting zone at a cutting speed of $100 \mathrm{~m} / \mathrm{min}$ for both diamond- $-\mathrm{TiB}_{2}-\mathrm{Co}$ and the commercial material. For the $v_{c}$ of $200 \mathrm{~m} / \mathrm{min}$, maximal temperatures of 1220 and $1450 \mathrm{~K}$ were attained for the composite with the titanium diboride bonding phase and the commercial cutting insert, respectively. The temperatures measured during the dry turning tests of titanium alloy are significantly higher than the temperatures indicated by the computational simulations, which may be due to the low thermal conductivity of Ti6Al4V alloy and its high affinity for the cutting inserts [23].

The roughness of the workpieces after turning (Fig. 7) for the $93 \%$ diamond $+5 \% \mathrm{TiB}_{2}+2 \% \mathrm{Co}$ and the commercial material are very similar. Above $50 \mathrm{~m} / \mathrm{min}$, no significant changes in roughness correspond to an increase in cutting 
speed; the roughness ranges from 0.5 to $1 \mu \mathrm{m}$ despite temperatures above $1400 \mathrm{~K}$ at higher cutting speeds. Surface roughness after titanium alloy turning with the use of diamond-Ti-Si-C-TiCN was significant with considerable improvement of the surface quality with an increase in cutting speed.

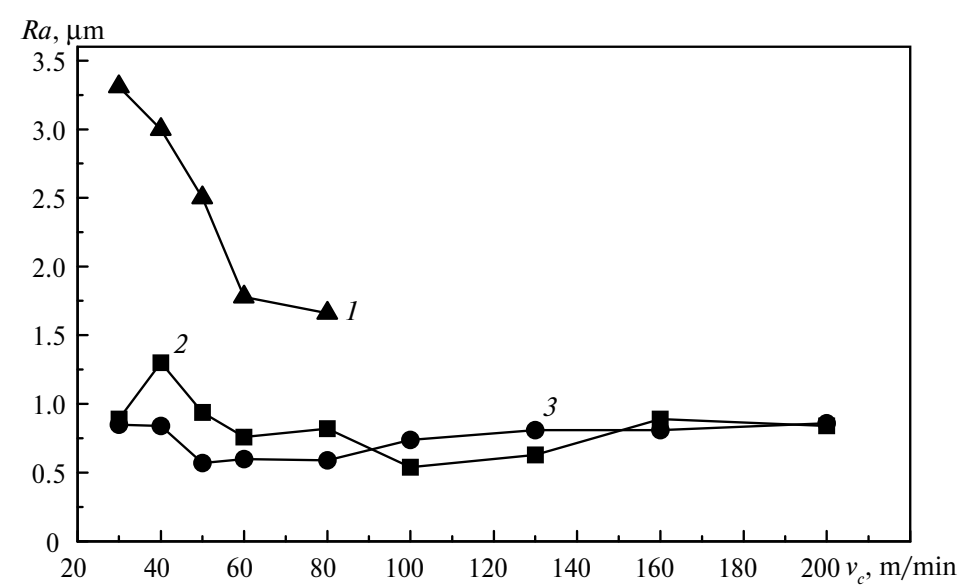

Fig. 7. Surface roughness at different cutting speeds for diamond-Ti-Si-C, diamond- $\mathrm{TiB}_{2}-\mathrm{Co}$ and commercial composite: $80 \%$ diamond $+15 \%(\mathrm{Ti}-\mathrm{Si}-\mathrm{C})+5 \%$ nano $\operatorname{TiCN}(1)$, $93 \%$ diamond $+5 \% \mathrm{TiB}_{2}+2 \% \mathrm{Co}(2), 88 \%$ diamond $+10 \% \mathrm{Co}+2 \% \mathrm{WC}$ (commercial) (3).

\section{CONCLUSIONS}

The temperature generated in the cutting zone for the composite with $5 \% \mathrm{TiB}_{2}$ and $2 \%$ Co is very similar to the commercial material with a cobalt bonding phase; for both of these materials, the roughness of the titanium alloy after turning is comparable.

For the cutting material with carbides (with a Ti-Si-C-TiCN system bonding phase), the temperature in the cutting zone is substantially higher, the roughness decreases with an increase in cutting speed and tool failure occurs at cutting speeds above $80 \mathrm{~m} / \mathrm{min}$.

The temperatures indicated by the computational simulations are significantly lower than the temperatures measured during the dry cutting tests; however, the temperature tendencies are comparable.

This study was supported in the 2007-2013 Innovative Economy Programme under the National Strategic Reference Framework EU, priority axis 1, section 1.1.3 No UDA-POIG.01.03.01-12-024/08-00, 26 March 2009 and the statutory activity of The Institute of Advanced Manufacturing Technology (DS-14.4.1).

Досліджено теплові властивості алмазних композитів з керамічними

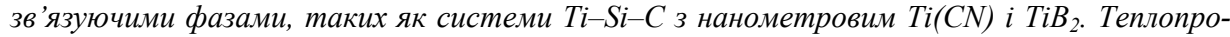
відності матеріалів проаналізовано за допомогою методу лазерного імпульсу. Крім того, методом скінченних елементів виконано числове моделювання залежності температури від відстані до ріжучої кромки для досліджених композитів, комериійного РСD $i$ гіпотетичного монокристалу алмазу. Розглянуто дві швидкості різання в ході числового обчислення: 100 і 200 м/хв. Для перевірки результатів моделювання використовували ріжучі пластини TNGA 160408, які було виготовлено з використанням досліджених алмазних композитів і комериійних матеріалів. Було проведено випробувальну обробку титанового сплаву. Температуру під час механічної обробки спостерігали з використанням термовізуальної камери, після випробувань вимірювали шорсткість поверхні. Числове моделювання підтвердило сильну залежність між тепловими властивостями оброблюваного мате- 
ріалу і температурою в зоні різання. Температурні вимірювання під час сухого різання показали значно вищі температури, ніж досягнуті в ході моделювання.

Ключові слова: алмазно-керамічний композит, термічні властивості, ріжучі інструменти, обробка.

Исследованы тепловые свойства алмазных композитов с керамическими связующими фазами, таких как системь Ti-Si-C с нанометровым Ti(CN) и TiB ${ }_{2}$ Tenлопроводности материалов проанализированы с помощяью метода лазерного импульса. Кроме того, методом конечных элементов выполнено числовое моделирование зависимости температуры от расстояния до режущей кромки для исследованньх композитов, коммерческого PCD и гипотетического монокристалла алмаза. Рассматривали две скорости резки в ходе числового вычисления: 100 и 200 м/мин. Для проверки результатов моделирования использовали режущче пластины TNGA 160408, которые были изготовлены с использованием исследованных алмазных композитов и коммерческих материалов. Была проведена испытательная обработка титанового сплава. Температуру при механической обработки наблюдали с использованием термовизуальной камеры, после испьтаний измеряли иероховатость поверхности. Числовое моделирование подтвердило сильную зависимость между тепловыми свойствами обрабатываемого материала и температурой в зоне резания. Температурные измерения при сухой резки показали значительно более высокие температуры, чем достигнутые в ходе моделирования.

Ключевые слова: алмазно-керамический композит, термические свойства, режущчие инструменты, обработка.

1. Burns R. C., Hansen J. O., Spits R. A. et al. Growth of high purity large synthetic diamond crystals // Diamond Relat. Mater. - 1999. - 89. - P. 1433-1437.

2. Hall H. T. Sintered diamonds: A synthetics carbonado // Science. - 1970. - 169, N 3948. P. 868-869.

3. Katzman H., Libby W. F. Sintered diamond compacts with a cobalt binder // Ibid. - 1974. 172. - P. 1132-1134.

4. Hibbs L. E. Jr., Wentorf R. H. Jr. High pressure sintering of diamond by cobalt infiltration // High Temp.-High Pess. - 1974 - 6. - P. 409-413.

5. Feenstra R. Status of polycrystalline-diamond-compact bits: part 2 applications // J. Petrol. Technol. - 1988. - 40. - P. 817-821.

6. Borowiecka-Jamrozek J. Engineering structure and properties of materials used as a matrix in diamond impregnated tools // Arch. Metall. - 2013. - 58. - P. 5-8.

7. Nath C., Rahman M., Neo K. S. A study on ultrasonic elliptical vibration cutting of tungsten carbide // J. Mater. Process. Technol. - 2009. - 209. - P. 4459-4464.

8. Butler-Smith P. W., Axinte D. A., Daine M. et al. A study of an improved cutting mechanism of composite materials using novel design of diamond micro-core drills // Int. J. Mach. Tool. Manu. - 2015. - 88. - P. 175-183.

9. Jaworska L., Szutkowska M., Klimczyk P. et al. Oxidation, graphitization and thermal resistance of PCD materials with the various bonding phases of up to $800{ }^{\circ} \mathrm{C} / /$ Int. J. Refract. Met. Hard Mater. - 2014. - 45. - P. 109-116.

10. Šajgalik M., Pilc J., Borovsky R. et al. Simultaneous monitoring of dynamic processes in the cutting zone turning of superalloys by using thermovision and high-speed cutting // Obrobka Skrawaniem Efektywne Wytwarzanie / Ed. P. Cichosz. - Wroclaw, Poland: Wroclawska Drukarnia, Naukowa PAN Sp.z.o.o., 2012 (in polish).

11. Schneider G. Jr. American Machinist. Chapter 1: Cutting Tool Materials, 13 Oct. 2009. Available at: [http://americanmachinist.com/cutting-tools/chapter-1-cutting-tool-materials].

12. Arsecularante J. A., Zhang L. C., Montross C. Wear and tool life of tungsten carbide, PCBN and PCD cutting tools // Int. J. Mach. Tool. Manuf. - 2006. - 46. - P. 482-491.

13. Jaworska L., Rozmus M., Laszkiewicz-Lukasik J. et al. Manufacturing of the cutting inserts using monolithic diamond compact // Obrobka Skrawaniem Efektywne Wytwarzanie / Ed. P. Cichosz. - Wroclaw, Poland: Wroclawska Drukarnia Naukowa PAN Sp.z.o.o., 2012 (in polish).

14. Jaworska L., Klimczyk P., Szutkowska M. et al. Thermal resistance of PCD materials with borides bonding phase // J. Superhard Mater. - 2015. - 37, N 3. - P. 155-165. 
15. Parker W. J., Jenkins R. J., Butler C. P., Abbott G. L. Flash method of determining thermal diffusivity, heat capacity and thermal conductivity // J. Appl. Phys. - 1961. - 32, N 9. P. 1679.

16. Cape J. A., Lehman G. W. Temperature and finite pulse-time effects in the flash method for measuring thermal diffusivity // Ibid. - 1963. - 34, N 7. - P. 1909.

17. User's Manual of AdvantEdge v5.9 Machining Simulation Software. - Minneapolis, US: MN, 2012.

18. Westraadt J. E., Dubrovinskaia $N$. Thermally stable polycrystalline diamond sintered with calcium carbonate // Diamond Relat. Mater. - 2007. - 16, N 11. - P. 1929-1935.

19. Shulzhenko A. A., Gargin V. G. Properties and structure of diamond polycrystals obtained at different sintering temperatures // Superhard Mater. - 1984. - 2, N 2. - P. 26-30.

20. Klimenko S. A., Mukovoz Yu. A., Polonsky L. G. Cutting tools of superhard materials // Key. Eng. Mater. - 1995 - 114. - P. 1-66.

21. Kidalov $S$. V., Shakhov F. M. Thermal conductivity of diamond composites // Materials. 2009. - 2, N 4. - P. 2467-2495.

22. Pierson $H$. $O$. Handbook of refractory carbides and nitrides: properties, characteristics, processing and applications. - NJ, USA: Noyes Publications, 1996.

23. Che-Haron C. H., Jawaid A. The effect of machining on surface integrity of titanium alloy Ti-6\% Al-4\% V // J. Mater. Process. Technol. - 2005. - 166, N 2. - P. 188-192.

Received 17.11.15 